\title{
Pengaruh Sekolah Secara Online terhadap Perilaku Sedentari yang Berisiko Obesitas pada Remaja Berumur 15-19 Tahun
}

\section{The Influence of Online School on Sedentary Behavior at Risk of Obesity in Adolescents Aged 15-19 Years}

\author{
Pika Asyera Sinulingga ${ }^{1}$, Lita Sri Andayani ${ }^{2}$, Zulhaida Lubis ${ }^{3}$ \\ Program Studi Ilmu Kesehatan Masyarakat, Universitas Sumatera Utara, Indonesia
}

\section{ARTICLE INFO}

\section{Article history}

Received date

13 Sep 2021

Revised date

05 Oct 2021

Accepted date

09 Nov 2021

\section{Keywords:}

Obesity;

Online school;

Sedentary behavior.

\section{Kata kunci:}

Obesitas;

Sekolah online;

Perilaku Sedentari.

\begin{abstract}
ABSTRAK
Obesity is the accumulation of excessive fat in the body as a result of an imbalance in the amount of energy that enters and leaves the body. One of the causes of obesity is sedentary behavior. Sedentary behavior makes the activity passive. Behavior changes are also happening at this time due to the Covid-19 pandemic. Pandemic makes all activities to be carried out from the home to prevent the spread of the Covid-19 virus, like studying from home. Online school is considered more passive than offline school because when a rest period that can be used for physical movement through interacting with friends like playing together. Whereas online school, teenagers are only more dominant in being silent in front of a laptop or smartphone. This study aims to determine the effect of online school on sedentary behavior at risk of obesity in adolescents. This type of research is a quantitative study using a cross-sectional design. The number of respondents in this study consisted of 267 people. Data was obtained through the results of questionnaires which were conducted online using Google Forms. The results showed that online schools had a high risk of sedentary behavior by $49,1 \%, 44.9 \%$ of moderate risk, and less risk by $6,0 \%$. Statistical test using chi-square obtained p-value $=0,008 \quad(<\alpha=0,05)$. So it can be concluded that there is an effect of online schooling on sedentary behavior that is at risk of obesity in adolescents aged 15-19 years in the city of Medan.
\end{abstract}

Obesitas adalah penumpukan lemak yang berlebihan di dalam tubuh akibat dari ketidakseimbangan jumlah energi yang masuk dan keluar dari dalam tubuh. Salah satu penyebab terjadinya obesitas adalah perilaku sedentari. Perilaku sedentari adalah suatu kegiatan yang tidak menimbulkan aktivitas fisik sehingga menyebabkan fisik menjadi pasif. Perilaku sedentari disebut juga perilaku bermalas-malasan. Perubahan perilaku juga sedang terjadi pada saat ini dikarenakan adanya pandemi Covid-19. Pandemi tersebut menyebabkan segala aktivitas dilakukan dari rumah untuk mencegah penyebaran virus Covid-19. Salah satu kegiatan yang dilakukan dari rumah adalah bersekolah dari rumah secara online. Sekolah secara online dinilai lebih pasif daripada sekolah tatap muka karena sekolah secara bertatap muka memiliki waktu beristirahat yang dapat dimanfaatkan untuk pergerakan fisik melalui berinterkasi kepada teman-teman seperti bermain bersama. Sedangkan sekolah secara online, remaja hanya lebih dominan diam di depan laptop atau smartphone pada waktu bersekolah. Penelitian ini bertujuan untuk mengetahui pengaruh sekolah secara online terhadap perilaku sedentari yang berisiko obesitas pada remaja. Jenis penelitian merupakan penelitian kuantitatif menggunakan desain cross sectional. Jumlah responden penelitian ini terdiri dari 267 orang. Data diperoleh melalui hasil lembar kuisioner yang dilakukan secara online menggunakan google form. Hasil penelitian menunjukkan sekolah secara online berisiko tinggi terhadap perilaku sedentari sebesar $49,1 \%$, cukup berisiko terhadap perilaku sedentari sebesar 44,9\%, dan kurang berisiko terhadap perilaku sedentari sebesar 6,0\%. Uji statistik menggunakan chi-square diperoleh nilai $p$-value $=0,0001 \quad(<\alpha=0,05)$. Sehingga dapat disimpulkan bahwa ada pengaruh sekolah secara online terhadap perilaku sedentari yang berisiko obesitas pada remaja berumur 15-19 tahun di kota Medan.

Corresponding Author:

Pika Asyera br Sinulingga

Program Studi Ilmu Kesehatan Masyarakat, Universitas Sumatera Utara, Indonesia

Email: pika.asyera@gmail.com 


\section{PENDAHULUAN}

Obesitas merupakan penumpukan lemak yang berlebihan akibat ketidakseimbangan asupan energi (energy intake) dengan energi yang digunakan (energy expenditure) dalam waktu lama (Kementerian Kesehatan RI, 2017). Obesitas telah mencapai proporsi epidemi secara global, dengan setidaknya 2,8 juta orang meninggal setiap tahun akibat kelebihan berat badan atau obesitas. Pernah dianggap sebagai masalah hanya di negara-negara berpenghasilan tinggi, kelebihan berat badan dan obesitas sekarang secara dramatis meningkat di negaranegara berpenghasilan rendah dan menengah, terutama di perkotaan (World Health Organization, 2020).

Kejadian obesitas di sebagian besar negara di Asia juga mengalami peningkatan secara dramatis dalam beberapa dekade terakhir (Morales, et al., 2019), dengan prevalensi overweight $14 \%$ dan obesitas $3 \%$ untuk wilayah Asia Tenggara dan untuk di wilayah Amerika Serikat. Dari data WHO (2017) juga menunjukkan prevalensi obesitas dari beberapa Negara di tahun 2016, yaitu Indonesia sebesar $6,9 \%$; Jepang sebesar $4,3 \%$; Singapura sebesar $6,1 \%$; China sebesar $6,2 \%$; dan India sebesar $3,9 \%$.

Obesitas di Indonesia juga selalu mengalami peningkatan dari tahun ke tahun. Hal ini dikuatkan oleh data Riset Kesehatan Dasar (RIKESDAS) 2018 yang mengalami kenaikan data obesitas dari tahun 2013 sampai 2018. Proporsi obesitas pada dewasa umur $>18$ tahun di Indonesia pada tahun 2013 adalah 14,8\% dan mengalami kenaikan pada tahun 2018 menjadi $21,8 \%$. Selain itu, proporsi obesitas sentral pada dewasa umur $\geq 15$ tahun di Indonesia juga mengalami peningkatan yaitu $26,6 \%$ pada tahun 2013 menjadi $31,0 \%$ pada tahun 2018. Peningkatan data proporsi obesitas di Indonesia tidak terlepas karena peningkatan proporsi obesitas yang terjadi di tingkat provinsi, salah satunya provinsi Sumatera Utara (Kementerian Kesehatan RI, 2018).

Peningkatan proporsi obesitas di Sumatera Utara juga telihat dari kenaikan proporsi obesitas sentral pada dewasa umur $\geq 15$ tahun yaitu $30 \%$ pada tahun 2013 menjadi 33\% pada 2018. Selain itu, proporsi obesitas pada dewasa umur $>18$ tahun juga mengalami peningkatan yaitu $17 \%$ pada tahun 2013 menjadi 25\% pada tahun 2018 (RISKESDAS, 2018). Peningkatan kasus obesitas juga terjadi di ibukota provinsi Sumatera
Utara yaitu kota Medan. Profil Kesehatan Kota Medan 2016 menunjukkan bahwa hasil cakupan pemeriksaan obesitas yang dilakukan pada umur $\geq 15$ tahun, terdapat 1.766 orang yang obesitas dari 11.175 orang yang dilakukan pemeriksaan Kementerian Kesehatan RI, 2016). Selain itu, berdasarkan Profil Kesehatan Sumatera Utara pada tahun 2017, dari 39.392 orang yang dilakukan pengukuran obesitas dengan umur $\geq 15$ tahun terdapat $1,31 \%$ atau sekitar 5.491 orang yang obesitas di Kota Medan (Kementerian Kesehatan RI, 2017).

Terjadinya jumlah peningkatan kasus obesitas dari tahun ke tahun tidak lepas karena adanya faktor-faktor penyebab yang berdampak pada terjadinya obesitas. Salah satunya yaitu adanya perubahan gaya hidup yang lebih memilih menjadi berperilaku sedentari dominan sehingga berdampak pada kasus obesitas (Gao Fan, et al., 2017).

Perilaku sedentari disebut aktivitas fisik yang kurang bergerak atau ketidakaktifan fisik. Perilaku sedentari adalah kegiatan yang mengacu pada segala jenis aktivitas yang dilakukan di luar waktu tidur, di mana postur duduk dan berbaring adalah posisi yang paling sering atau paling dominan yang dilakukan dengan karakteristik keluaran kalori sangat sedikit yakni <1,5 METs (Kementerian Kesehatan, 2019). Perilaku sedentari menyebabkan banyak energi yang tersimpan sebagai lemak, sehingga orang-orang yang kurang melakukan aktivitas cenderung menjadi gemuk, dan dapat mengakibatkan penyakit PTM lainnya serta dapat menyebabkan kematian.

Data World Health Organization (2018) menyatakan bahwa sekitar 2 juta kematian per tahun disebabkan oleh perilaku sedentari. Selain itu, 60 hingga $85 \%$ orang di dunia baik dari negara maju maupun negara berkembang menjalani gaya hidup perilaku sedentari dan empat dari lima remaja (11-17 tahun) tidak melakukan aktivitas fisik yang cukup. Data tersebut juga menyatakan bahwa 23\% orang dewasa dan $81 \%$ remaja tidak memenuhi rekomendasi global WHO tentang aktivitas fisik untuk kesehatan. Sehingga gaya hidup yang mendominasi saat ini adalah gaya hidup perilaku sedentari.

Penuruan aktivitas saat ini juga terjadi akibat adanya kasus pandemi Covid-19 (Sibarani, 2021). Covid-19 menyebar dari Cina ke seluruh dunia yang menyebabkan berbagai kegiatan menjadi terhambat. Penurunan aktivitas fisik disebabkan karena diberlakukannya physical 
distancing dan membatasi pergerakan seseorang untuk keluar rumah untuk mencegah penularan virus. Kondisi tersebut berdampak pada pekerjaan atau kegiatan harus dilakukan dari rumah. Salah satunya adalah pendidikan yang juga tidak terlepas dari dampakpenyebaran virus tersebut. Untuk memutuskan mata ratai penyebaran Covid-19 kegiatan sekolah maupun kuliah harus dilakukan dari rumah. (Nugraha, et al., 2020). Namun ada kemungkinan bahwa tinggal di rumah yang lama dapat menyebabkan peningkatan perilaku duduk, berbaring, bermain game, menonton televisi, dan menggunakan perangkatseluler sehingga membuat pengeluaran energi yang kurang dan akibatnya adalah mengarah pada peningkatan resiko penyakit tidak menular (Nurmidin, et al., 2020).

Berdasarkan uraian tersebut maka perlu dilakukan penelitian dengan tujuan untuk mengetahui pengaruh sekolah secara online terhadap perilaku sedentari yang berisiko obesitas pada remaja berumur 15-19 tahun di kota Medan.

\section{METODE}

Jenis penelitian dalam penelitian ini adalah penelitian kuantitatif dengan menggunakan desain cross sectional. Lokasi penelitian dilakukan di kota Medan, dengan mengambil 20\% dari 21 kecamatan di kota Medan. Penentuan lokasi kecamatan dipilih dengan menggunakan teknik cluster random sampling dengan menyusun daftar nama kecamatan berdasarkan dari kecamatan yang terluas, setelah itu dipilih secara acak. Sehingga diperoleh lokasi penelitian yaitu Medan Amplas, Medan Baru, Medan Timur, dan Medan Tuntungan. Pada lokasi terpilih kemudian dilakukan penelitian secara online dengan menggunakan google form.

Populasi remaja berumur 15-19 tahun di 4 kecamatan lokasi penelitian berjumlah 39.199 orang. Sehingga jumlah sampel yang didapatkan menggunakan tabel ISSAC dan MICHAEL adalah 267 orang dengan derajat kesalahan 10\%. Penentuan sampel pada penelitian ini menggunakan teknik purposive sampling dengan kreteria inklusi yaitu tinggal di lokasi penelitian; remaja berumur 15-19 tahun; memiliki smartphone; dan mampu mengaplikasikan google form.

Teknik pengumpulan data pada penelitian ini adalah dengan memberikan daftar pertanyaan dan jawaban secara online dengan menggunakan google form. Daftar pertanyaan yang diberikan kepada responden telah mendapatkan persetujuan dari Komite Etik Pelaksanaan Penelitian Kesehatan dengan nomor 460/KEP/USU/2021. Teknik analisis data pada penelitian ini adalah analisis univariat untuk memperoleh distribusi frekuensi dari sekolah secara online, dan analisis bivariat dengan menggunakan uji chi-square untuk melihat pengaruh sekolah secara online terhadap perilaku sedentari yang berisiko obesitas dengan tingkat kepercayaan $95 \%$.

\section{HASIL}

Tabel 1. Distribusi Frekuensi Sekolah secara Online

\begin{tabular}{lrr}
\hline \multicolumn{1}{c}{ Sekolah secara online } & n & \% \\
\hline Berisiko tinggi & 131 & 49,1 \\
Cukup berisiko & 120 & 44,9 \\
Kurang berisiko & 16 & 6,0 \\
\hline
\end{tabular}

Adapun yang menjadi aspek pengukuran diklasifikasikan dalam tiga kategori yaitu:

a) School from home berisiko tinggi, apabila nilai responden $>75 \%$ dari nilai keseluruhan (80-100) atau benar 8-10 dari total 10 soal.

b) School from home cukup berisiko, apabila nilai responden $40 \%-75 \%$ dari nilai keseluruhan (40-70) atau benar 4-7 soal dari total 10 soal.

c) School from home kurang berisiko, apabila nilai responden $<40 \%$ dari nilai keseluruhan (0-30) atau benar 0-3 soal dari total 10 soal.

Sehingga dapat dilihat bahwa hasil penelitian menunjukkan bahwa dari 267 orang terdapat sebanyak 131 orang $(49,1 \%)$ responden berisiko tinggi melakukan perilaku sedentari, sebanyak 120 orang $(44,9 \%)$ responden cukup berisiko melakukan perilaku sedentari, dan sebanyak 16 orang $(6,0 \%)$ responden kurang berisiko melakukan perilaku sedentari.

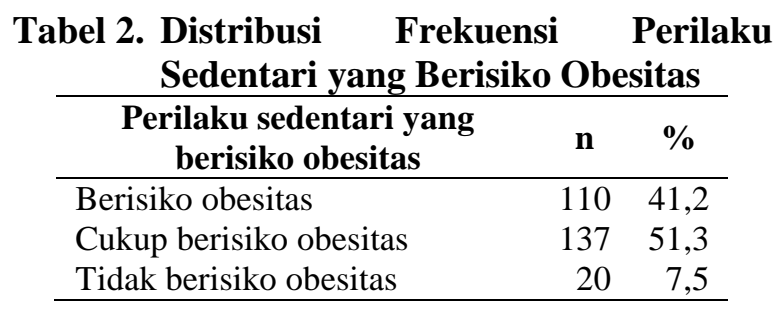

Adapun yang menjadi aspek pengukuran diklasifikasikan dalam tiga kategori yaitu: 
a) Perilaku sedentari yang berisiko obesitas, apabila nilai responden $>75 \%$ dari nilai keseluruhan (80-100) atau benar 8-10 dari total 10 soal.

b) Perilaku sedentari yang cukup berisiko obesitas, apabila nilai responden 40\%-75\% dari nilai keseluruhan (40-70) atau benar 4-7 soal dari total 10 soal.

c) Perilaku sedentari yang tidak berisiko obesitas, apabila nilai responden $<40 \%$ dari nilai keseluruhan (0-30) atau benar 0-3 soal dari total 10 soal.

Berdasarkan tabel 2 menunjukkan data responden berperilaku sedentari yang berisiko obesitas yaitu sebanyak 110 orang $(41,2 \%)$ berisiko obesitas, sebanyak 137 orang $(51,3 \%)$ cukup berisiko obesitas dan sebanyak 20 orang $(7,5 \%)$ tidak berisiko obesitas.

Tabel 3. Pengaruh Sekolah Secara Online terhadap Perilaku Sedentari yang Berisiko Obesitas

\begin{tabular}{|c|c|c|c|c|c|c|c|c|c|}
\hline \multirow{3}{*}{ Sekolah secara online } & \multicolumn{6}{|c|}{ Perilaku Sedentari yang Berisiko Obesitas } & \multicolumn{2}{|c|}{ Total } & \multirow{3}{*}{$p$-value } \\
\hline & \multicolumn{2}{|c|}{ Berisiko } & \multicolumn{2}{|c|}{ Cukup } & \multicolumn{2}{|c|}{ Tidak } & \multirow{2}{*}{$\mathbf{n}$} & \multirow{2}{*}{$\%$} & \\
\hline & $\mathbf{n}$ & $\%$ & n & $\%$ & n & $\%$ & & & \\
\hline Berisiko tinggi & 70 & 26,2 & 61 & 22,9 & 0 & 0 & 131 & 49,1 & \\
\hline Cukup berisiko & 40 & 15,0 & 67 & 25,0 & 13 & 4,9 & 120 & 44,9 & 0,0001 \\
\hline Kurang berisiko & 0 & 0 & 9 & 3,3 & 7 & 2,7 & 16 & 6,0 & \\
\hline
\end{tabular}

Untuk melihat pengaruh antara sekolah secara online terhadap perilaku sedentari yang berisiko obesitas dilakukan dengan menggunakan uji chi-square. Dari tabel 3 dapat diketahui bahwa remaja yang berisiko tinggi berperilaku sedentari dan berisiko obesitas sebanyak 70 orang $(26,2 \%)$, dan remaja yang kurang berisiko berperilaku sedentari dan tidak berisiko obesitas sebanyak 7 orang $(2,7 \%)$. Hasil uji statistik dengan menggunakan uji chi-square memperoleh nilai $p$-value sebesar 0,0001 atau nilai $p$-value $<\alpha=0,05$ dengan derajat kepercayaan $95 \%$. Sehingga dapat disimpulkan bahwa ada pengaruh sekolah secara online terhadap perilaku sedentari yang berisiko obesitas pada remaja berumur 15-19 tahun di kota Medan.

\section{PEMBAHASAN}

Obesitas merupakan penimbunan lemak yang tidak normal atau berlebih yang bisa mengganggu kesehatan (World Health Organization, 2020). Penyebab terjadinya obesitas dipengaruhi banyak hal seperti faktor keturunan atau genetik, pola makan, dan aktivitas fisik. Faktor genetik memberikan peluang bagi anak untuk obesitas sebesar $40-50 \%$ apabila salah satu orangtuanya obesitas. Apabila kedua orangtuanya obesitas, maka peluang faktor keturunan menjadi obesitas sebesar 70-80\% (Kementerian Kesehatan RI, 2019). Selain itu, pola makan yang kurang teratur juga mampu menimbulkan obesitas. Pola makan yang dapat menyebabkan obesitas yaitu seperti pengonsumsian makan yang sudah diolah dengan minyak, pengonsumsian makanan tinggi garam, gula, lemak, santan, serta sering mengonsumsi camilan, menambah prosi makan malam, tidak sarapan, jam makan yang berantakan, serta kekurangan buah dan sayur.

Selain faktor genetik dan pola makan, aktivitas fisik juga sangat berpengaruh terhadap terjadinya obesitas. Aktivitas fisik yang teratur adalah contoh aspek pelindung yang paling penting untuk pencegahan dan pengobatan Penyakit Tidak Menular (PTM), contohnya kanker payudara, diabetes, stroke, penyakit jantung, hipertensi, kelebihan berat badan (overweight), obesitas, dan kemunculan demensia yang terlambat serta kenaikan mutu kesejahteraan serta hidup. Bukan hanya kesehatan, meningkatkan peran serta dalam aktivitas fisik juga menghasilkan berbagai kegunaan ekonomis dan sosial (World Health Organization, 2020).

Aktivitas fisik yang kurang bergerak disebut juga ketidakaktifan fisik atau perilaku sedentari. Perilaku sedentari (sedentary) adalah kegiatan yang mengacu pada segala jenis aktivitas yang dilakukan di luar waktu tidur, dengan karakteristik keluaran kalori sangat sedikit yakni <1,5 METs. Perilaku Sedentari perlu dibatasi karena berbagai penelitian memperlihatkan bahwa perilaku ini menjadi risiko munculnya Obesitas (Kementerian Kesehatan RI, 2019). Contoh perilaku sedentari berdasarkan Kementerian Kesehatan RI (2018) yaitu berbaring atau duduk dalam waktu lama, seperti menonton televisi, bermain video game, duduk lama di depan komputer; anak-anak pergi ke sekolah dengan 
diantar menggunakan kendaraan meskipun jaraknya dekat; perubahan kebiasaan misalnya orang pergi ke toko atau mini market hanya berjarak beberapa rumah dari tempat tinggalnya menggunakan mobil atau motor pekerjaan rumah diserahkan kepada pembantu; kurang berolahraga; selalu menggunakan kendaraan bermotor untuk mencapai tempat yang jaraknya dekat; menggunakan lift meskipun akses tangga tersedia.

Selain dari perilaku sedentari kecenderungan terjadinya obesitas dapat disebabkan oleh asupan pola makan yang salah seperti makan yang tidak teratur, cemilan yang tinggi karbohidrat dan lemak, mengonsumsi junk food ataupun fast food. Terlebih lagi pada saat ini sedang terjadi masa pandemi Covid-19. Pandemi tersebut menyebabkan segala aktivitas dominan dilakukan dari dalam rumah. Keterbatasan aktivitas yang dilakukan juga dapat berdampak pada peningkatan pola konsumsi seperti cemilan yang tinggi lemak dan karbohidrat. Pada saat ini remaja suka mengonsumsi cemilan yang tinggi lemak dan gurih yang berasal dari penyedap makanan seperti makanan ringan dan mengonsumsi soft drink yang tinggi gula pada saat menonton tv ataupun netflix atau media komersial lain. Selain itu remaja saat ini juga dikenal dengan remaja atau "generasi micin".

Salah satu dampak lain terjadinya Pandemi Covid-19 adalah keterbatasan aktivitas sehingga kegiatan belajar mengajar harus dilakukan dari rumah secara online. Sekolah dari rumah merupakan suatu kebijakan yang dilakukan Pemerintah sebagai bentuk pencegahan dan penularan terjadinya Covid-19. Kebijakan untuk dilakukannya sekolah dari rumah beserta panduan dan pedomannya dipublikasikan oleh Kementerian Pendidikan dan Kebudayaan Republik Indonesia melalui Surat Edaran No. 3 Tahun 2020 tentang Pencegahan Corona Virus Disease (Covid-19) pada Satuan Pendidikan, Surat Edaran No. 4 Tahun 2020 tentang Pelaksanaan Kebijakan Pendidikan dalam Masa Darurat Penyebaran Corona Virus Disease (Covid-19), dan Surat Edaran No. 15 Tahun 2020 tentang Pedoman Penyelenggaraan Belajar dari Rumah dalam Masa Darurat Penyebaran Corona Virus Disease (Covid-19). Kebijakan tersebut dilakukan agar berkurangnya interaksi terhadap sesama sehingga diharapkan dapat memutuskan mata rantai penyebaran Covid-19.

Sekolah dari rumah diharapkan dapat memutus mata rantai penyebaran virus karena mengurangi interaksi kepada orang lain. Namun kegiatan sekolah dari rumah mengakibatkan penurunan aktivitas fisik. Hal tersebut dinyatakan King (2020) bahwa pembatasan terkait Covid-19 kemungkinan memperburuk masalah kesehatan masyarakat saat ini berupa rendahnya aktivitas fisik dan tingginya prevalensi perilaku menetap pada anak-anak dan remaja. Selain itu hasil penelitian Nurhadi dan Fatahillah (2020) menyatakan bahwa terjadi penurunan aktivitas fisik selama pandemi Covid-19 pada masyarakat sekitar Komplek Pratama, Kelurahan Medan Tembung.

Dari hasil penelitian didapatkan bahwa dari 267 orang terdapat sebanyak 131 orang $(49,1 \%)$ responden berisiko tinggi melakukan perilaku sedentari. Dari data ini dapat disimpulkan bahwa remaja dominan melakukan perilaku sedentari pada saat sekolah secara online. Hal ini dapat terjadi karena keterbatasan pengajar dalam mengawasi perilaku murid ketika sekolah secara online yang tidak dapat melihat langsung semua kegiatan murid ketika sekolah sedang berlangsung. Selain itu kegiatan sekolah dari rumah secara virtual dominan hanya diam sambil menatap layar laptop atau smartphone. Sehingga remaja lebih banyak menghabiskan waktu berperilaku sedentari selama sekolah secara online atau virtual dari rumah. Aktivitas fisik yang dilakukan remaja pada saat pandemi Covid-19 berbeda dengan sebelum pandemi. Ekstrakurikuler sekolah ataupun di kampus seperti olahraga renang, tari, pramuka, paskibra dan lainnya tidak dilakukan oleh remaja dikarenakan masa pandemi, sehingga aktivitas yang dilakukanjuga berkurang dari sebelumnya. (Rukmana, et al., 2020).

Selain itu jam belajar pada saat sekolah online dinilai lebih cepat daripada saat sekolah secara offline. Sehingga remaja memiliki waktu luang yang lebih banyak untuk bermain. Namun remaja saat ini cenderung bermain secara online dengan menggunakan handphone dalam genggaman sehingga pergerakan tubuh juga pasif. Penggunaan smartphone pada remaja tidak dapat dibatasi oleh orangtua karena penggunaan smartphone tersebut dijadikan alasan sebagai kebutuhan sekolah seperti sedang belajar atau sedang dalam menggerjakan tugas. Kenyamanan dan kecanggihan smartphone menyebabkan para pengguna terlena dan menjadi malas bergerak termasuk berolahraga.

Pemicu agar aktivitas fisik dilakukan oleh remaja dapat menggunakan influencer atau public figure. Perilaku influencer atau public figure dijadikan contoh bagi remaja yang 
mengidolakannya. Selain itu pada saat ini banyak public figure yang menggunakan aplikasi tiktok. Aplikasi tiktok merupakan sebuah jaringan sosial dan platform video musik. Aplikasi ini dapat dimanfaatkan untuk membuat video pribadi secara singkat. Remaja saat ini juga banyak mengakses dan menggunakannya serta mengikuti gerakan yang dibuat oleh public figure yang mereka idolakan dan mereka sukai sehingga tiktok juga dapat menimbulkan aktivitas fisik dan menjadi wadah untuk kreativitas bagi remaja.

Selain itu untuk meningkatkan aktivitas fisik bagi remaja juga dapat dengan membuat suatu aplikasi untuk dapat melakukan aktivitas fisik baik secara online maupun offline. Berdasarkan aplikasi tersebut dapat membentuk suatu komunitas agar remaja dapat melakukan aktivitas fisik secara bersamaan dan saling mengingatkan serta mendukung satu dengan yang lainnya baik secara online maupun offline. Sehingga remaja dapat memiliki kebiasaan aktivitas fisik atau olahraga yang baik, dan dapat mengurangi risiko terjadinya obesitas.

Hal lain yang menjadi perbandingan ketika sekolah secara online maupun offline adalah: ketika sekolah secara offline remaja memiliki pergerakan ketika pergi kesekolah dan pulang kerumah, selain itu remaja memiliki jam istirahat yang biasanya dipergunakan remaja untuk melakukan pergerakan seperti pergi ke kantin atau bermain bersama teman, selain itu remaja juga memiliki jam olahraga 1 minggu sekali dan adanya kegiatan upacara serta ekstrakurikuler lain yang disediakan sekolah sehingga menimbulkan aktivitas fisik bagi remaja. Namun hal tersebut tidak bisa dilakukan ketika sekolah secara online. Sekolah secara online memiliki banyak keterbatasan, sehingga segala aktivitas remaja sulit dipantau.

Dalam penelitian ini, school from home memiliki tingkatan berisiko tinggi dalam mendukung perilaku sedentari yang berisiko obesitas, sehingga harus diselaraskan dengan aktivitas fisik yang aktif selama di rumah. Jadi walaupun kegiatan belajar yang dilakukan dari rumah dapat menimbulkan terjadinya perilaku sedentari, hal tersebut bisa diatasi dengan adanya aktivitas fisik yang lain di luar dari kegiatan belajar.

Aktivitas fisik tetap bisa dilakukan walaupun school from home ketika adanya kerjasama dengan sekolah untuk menyediakan sela waktu agar melakukan peregangan dengan ketentuan waktu yang disepakati. Peregangan tersebut dilakukan sesuai dengan ketentuan seperti adanya gerakan yang harus diikuti oleh remaja dan gerakan tersebut merupakan gerakan yang dimungkinkan dapat dilakukan dan diikuti oleh remaja karena keterbatasan sekolah dari rumah, selain itu remaja juga harus menghidupkan kamera ketika kegiatan tersebut berlangsung, serta mengirim bukti video bahwa kegiatan tersebut benar dilakukan remaja tersebut. Harapan dari adanya kesepakatan tersebut adalah walaupun sekolah secara online, remaja tetap dapat melakukan aktivitas fisik agar tidak berisiko terjadinya obesitas.

Kegiatan yang terbatas dari remaja selama phisycal distancing juga membuat remaja menghabiskan waktu untuk berperilaku sedentari seperti rebahan, menonton Youtube atau serial drama, bermain game dengan smartphone. Hal ini dilakukan remaja untuk mengisi kekosongan waktu karena keterbatasan kegiatan yang dilakukan dari rumah. Orang tua juga tidak dapat membatasi kegiatan perilaku sedentari pada remaja tersebut karena orang tua memberikan kebebasan kegiatan selama aktivitas tersebut dilakukan di dalam rumah dan tidak ada interaksi langsung dengan orang lain untuk menghindari penyebaran virus corona.

Hasil penelitian diketahui hasil bahwa responden berperilaku sedentari yang berisiko obesitas yaitu sebanyak 110 orang $(41,2 \%)$ berisiko obesitas dan sebanyak 137 orang $(51,3 \%)$ cukup berisiko obesitas. Dari data ini dapat diketahui bahwa kegiatan perilaku sedentari yang dilakukan remaja cukup berisiko terhadap terjadinya obesitas. Hasil penelitian Rundle (2020) mengatakan bahwa melalui penutupan sekolah dapat memperburuk epidemi obesitas pada masa kanak-kanak dan meningkatkan disparitas dalam risiko obesitas.

Berdasarkan penelitian ini juga didapatkan hasil uji statistik antara sekolah secara online terhadap perilaku sedentari yang berisiko obesitas dengan nilai $p$-value sebesar 0,0001 atau nilai $p$-value $<\alpha=0,05$ dengan derajat kepercayaan $95 \%$. Sehingga dapat disimpulkan bahwa ada pengaruh sekolah secara online terhadap perilaku sedentari yang berisiko obesitas pada remaja berumur 15-19 tahun di kota Medan. Perilaku sedetari dapat menyebabkan terjadinya obesitas. Sehingga diperlukannya perilaku sehat seperti melakukan aktivitas fisik dan menjaga pola makan. Obesitas pada masa remaja dapat meningkatkan risiko penyakit kardiovaskuler ketika dewasa. Sehingga perilaku sedentari harus diminimalisir dalam kehidupan sehari-hari untuk mencegah 
terjadinya obesitas. Hal ini sejalan dengan hasil penelitian Nurmidin (2020) yang menyatakan bahwa terdapat pengaruh pandemi Covid-19 terhadap aktivitas fisik dan penerapan prinsip gizi seimbang. Selain itu penelitian Callow (2020) juga menyatakan bahwa aktivitas fisik yang rendah berhubungan dengan timbulnya gangguan mental selama pandemi.

Aktivitas fisik juga dapat membantu untuk meningkatkan sistem imun sehingga tubuh dapat terhindar dari infeksi (Callow, et al., 2020). Aktivitas fisik yang dilakukan secara teratur memiliki efek yang luar biasaterhadap kesehatan (Nurhadi \& Fatahillah, 2020). Selama masa pandemi Covid-19 setiap orang dihimbau untuk menjaga kesehatan dengan mengkonsumsi makanan bergizi dan olahraga secara teratur (Nugraha, et al., 2020). Usaha pencegahan tertularnya Covid-19 juga dapat dilakukan

\section{DAFTAR PUSTAKA}

Ashadi, K., Mita Andriana, L., \& Pramono, B. A. (2020). Pola aktivitas olahraga sebelum dan selama masa pandemi covid-19 pada mahasiswa fakultas olahraga dan fakultas nonolahraga. Jurnal SPORTIF: Jurnal Penelitian Pembelajaran, 6(3), 713-728. https://doi.org/10.29407/js_unpgri.v6i 3.14937.

Callow, Daniel D., Arnold-Nedimala, Naomi A., Jordan, Leslie S., Pena, Gabriel S., Won, Junyeon, Woodard, John L., \& Smith, J. Carson. (2020). The Mental Health Benefits of Physical Activity in Older Adults Survive the COVID-19 Pandemic. American Journal of Geriatric Psychiatry, 28(10), 1046-1057. https://doi.org/10.1016/j.jagp.2020.0 6.024

Dinas Kesehatan Provinsi Sumatera Utara. (2017). Profil Kesehatan Provinsi Sumatera Utara. Medan

Gao Fan, Jian., et al. (2017). New Trends on Obesity and NAFLD in Asia. doi: 10.1016/j.jhep.2017.06.003

Kementerian Kesehatan RI. (2016). Profil Kesehatan Kota Medan 2016. Medan.

Kementerian Kesehatan RI. (2017). Panduan Pelaksanaan Gerakan Nusantara Tekan Angka Obesitas (GENTAS). Jakarta: Direktorat Pencegahan dan Pengendalian Penyakit Tidak Menular Kementrian Kesehatan Republik Indonesia.

Kementerian Kesehatan RI. (2017). Profil Kesehatan Sumatera Utara 2017. dengan meningkatkan kualitas fisik tubuh (Mondal, et al. dalam Ashadi, et al., 2020). Aktivitas fisik dan olahraga akan lebih berdampak positif pada kesehatan apabila didukung dengan asupan gizi yang tepat. Kecukupan gizi tentunya juga berpengaruh terhadap kondisi kesehatan dan kebugaran tubuh (Naja dalam Nugraha, et al., 2020).

\section{SIMPULAN}

Terdapat pengaruh sekolah secara online terhadap perilaku sedentari yang berisiko obesitas pada remaja berumur 15-19 tahun di kota Medan. Semakin tinggi risiko sekolah secara online terhadap perilaku sedentari, maka remaja akan semakin berisiko obesitas.

Kementerian Kesehatan RI. (2018). Riset Kesehatan Dasar Tahun 2018. Jakarta: Badan Penelitian dan Pengembangan Kesehatan.

Kementerian Kesehatan RI. (2018). Contoh Perilaku Sedentari (1). http://p2ptm.kemkes.go.id/infographicp2ptm/obesitas/contoh-perilaku-sedentari-1

Kementerian Kesehatan RI. (2018). Contoh Perilaku Sedentari (2). http://www.p2ptm.kemkes.go.id/infographic -p2ptm/obesitas/contoh-perilaku-sedentari-2

Kementerian Kesehatan RI. (2019). Yuk, Mengenal Apa Itu Kegiatan Sedentari?. http://www.p2ptm.kemkes.go.id/infograph ic-p2ptm/obesitas/page/11/yuk -mengenalapa-itu-kegiatan-sedentari.

King, A.J.; Burke, L.M.; Halson, S.L.; Hawley, J.A. (2020). The Challenge of Maintaining Metabolic Health During a Global Pandemic. Sport. Med., 50, 1233-1241.

Morales Camacho, W. J., Molina Díaz, J. M., Plata Ortiz, S., Plata Ortiz, J. E., Morales Camacho, M. A., \& Calderón, B. P. (2019). Childhood obesity: aetiology, comorbidities, and treatment. Diabetes/metabolism research and reviews, 35(8), e3203.

Nugraha, P. D., Utama, M. B. R., S, A., \& Sulaiman, A. (2020). Survey of Students Sport Activity During Covid-19 Pandemic. Jp.Jok (Jurnal Pendidikan Jasmani, 
Olahraga Dan Kesehatan), 4(1), 11-24. https://doi.org/10.33503/jp.jok.v4i1.8 05

Nurhadi, J. Z. L., \& Fatahillah. (2020). Pengaruh Pandemi Covid-19 Terhadap Tingkat Aktivitas Fisik Pada Masyarakat Komplek Pratama, Kelurahan Medan Tembung. Jurnal Health Sains, 1(5), 294-298.

Nurmidin, M., Fatimawali, \& Posangi, J. (2020). Pengaruh Pandemi Covid-19 Terhadap Aktivitas Fisik dan Penerapan Prinsip Gizi Seimbang pada Mahasiswa Pascasarjana. Journal of Public Health and Community Medicine, 28-32. https://ejournal.unsrat.ac.id/index.php /ijphcm/article/view/31169.

Rukmana, E., \& Tyas Permatasari, E. E. (2020). Hubungan Antara Aktivitas Fisik Dengan Status Gizi Pada Remaja Selama Pandemi Covid-19 Di Kota Medan. Jurnal Dunia Gizi, 3(2), 88-93.

Rundle, A. G., Park, Y., Herbstman, J. B., Kinsey, E. W., \& Wang, Y. C. (2020). COVID-19 related school closings and risk of weight gain among children. Obesity (Silver Spring, Md.), 28(6), 1008.

Sibarani, I. H. (2021, April 20). Pengaruh Pandemi Covid-19 Terhadap Penurunan Aktivitas Fisik Pada Remaja Selama Lockdown. OSF Pre Prints. https://doi.org/10.31219/osf.io/v39tx.

World Health Organization. (2017). Prevalence of obesity among adults, $B M I \geq 30$, agestandardized estimates by $\mathrm{WHO}$ region. Global Health Observatory data repository.

https://apps.who.int/gho/data/view.main.R EGION2480A?lang=en

World Health Organization. (2018). Physical activity. https://www.who.int/newsroom/facts-in-pictures/detail/physicalactivity.

World Health Organization. (2020). Obesity. https://www.who.int/features/factfiles/obes ity/en/. 